\title{
Practitioners' Perspectives on the Application of Integration Theory in the Saudi EFL Context
}

\author{
Mansoor S. Almalki ${ }^{1} \&$ Abdul Fattah Soomro ${ }^{2}$ \\ ${ }^{1}$ English Language Centre, Deanship of Supportive Studies, Taif University, Saudi Arabia \\ ${ }^{2}$ English Language Centre, Deanship of Supportive Studies, Taif University, Saudi Arabia \\ Correspondence: Mansoor S. Almalki, English Language Centre, Deanship of Supportive Studies, Taif \\ University, P. O. Box 888, Taif 21974, Saudi Arabia. E-mail: msamalki@tu.edu.sa
}

Received: March 1, 2017 Accepted: May 20, 2017 Online Published: May 26, 2017

doi: 10.5539/elt.v10n6p93 URL: http://doi.org/10.5539/elt.v10n6p93

\begin{abstract}
There is a close connection between reading and writing. Several studies suggest integrating reading in the instruction of teaching writing skills to English as a Foreign Language (EFL) learner. This study seeks to determine the extent Saudi EFL teachers support, apply and understand the theory of integration between reading and writing. To achieve the research objectives, the researcher compiled two lesson plans; one based on the integration theory and the other, based on a traditional model to see which lesson plan teacher-participants chose to teach writing. The data was then collected through questionnaire containing both closed and open-ended questions to determine the implications of the results in relation to the objectives of the research. The major findings of this research project were that, for the ten EFL teachers surveyed, most of the teachers indicated that they usually taught writing as a separate skill apart from reading, and the written responses from the open-ended questions that was analyzed indicated that the teachers taught writing in the traditional way. The results from the ten participants' responses also suggested that almost none of the participants were familiar with the concept of integrating reading and writing for the purposes of teaching writing. However, most of the respondents did comment that they agree with the idea of integrating reading in the instruction of teaching the writing skills and given a choice of a lesson plan, most of the teachers choose the integrated lesson plan.
\end{abstract}

Keywords: theory of integration, reading-writing connection, traditional model, EFL context of Saudi Arabia

\section{Introduction}

There is a practical relationship between reading and writing (Alderson \& Urquhart, 1984). The large number of research studies suggest that teaching writing skills through reading is more effective mode of instruction than merely focusing on exclusive teaching writing skills in EFL classes (Alqadi \& Alqadi, 2013; Almansour \& Alshorman, 2014; Hafiz \& Tudor, 1989; Iwahori, 2008; Janopoulos, 2009; Saleem, 2010; Tsang, 1996). Carson \& Leki, (1993) suggest that reading serves as a foundation for developing the writing skills. Neuman (1989) commented that one must understand his/her readers before even conceiving the idea of writing. However, for a long time, writing and reading have been taught as completely separate skills (Calkins, 1986). According to Kroll (1994), both reading and writing are strongly related in that they exist within a larger concept, the context. According to Kroll (1994), without a context, reading and writing are meaningless. That is, to write, a text is needed. One cannot move from a text to writing. The text needs to be read, and understood, before a meaningful response can be written (Carrell and Eisterhold, 1983; Kroll, 1994). Another link between reading and writing is that humans have an innate desire to read and write, as Calkins (1986) commentsthat people write because they want to understand their lives, they read because they want to understand others's lives.

Several research studies have indicated that Saudi EFL teachers focus less on reading-writing connection in their instruction of teaching writing skills which is considered a main reason for weak writing skills among EFL Saudi learners (Fageeh, 2003 cited in Alomrani, 2014). The leaners are not able to develop the required writing skills because reading and writing skills are taught separately (Alomrani, 2014). According to Hao and Sivell (2002), isolating teaching writing skills from integrating reading, creates a great deal of difficulties for leaners to develop their writing skills. They further maintain that when writing instruction does not include a reading text, the leaners are unable to transfer acquired knowledge and skills from reading to writing. 


\subsection{Research Objectives}

The project has the aim of improving teaching and learning of writing through the effective use of reading activities. To best understand the current writing classroom environment, there is a need to compare and contrast strategies currently used by Saudi EFL teachers in the second language (L2) classroom. The research also aims to study the effectiveness of lesson plans developed based on the tenets of the theory of integration between reading and writing as recommended in the body of literature. The main objectives of the research are:

- To determine the extent Saudi EFL teachers support the theory of integration between reading and writing.

- To know if Saudi EFL teachers understand the theory of integration between reading and writing.

- $\quad$ To what extent Saudi EFL teachers apply the theory of integration between reading and writing

\subsection{Significance of the Study}

The notion of teaching writing and reading is not one which historically has been commented on explicitly in published form in Saudi Arabia. Few articles in either Arabic or English, have been written commenting on the way that EFL teachers teach either writing or reading in the classroom. Most of the discourse available deals with English language teaching or English language assessment rather on the teaching of writing and reading in the Kingdom of Saudi Arabia. However, very recently, there has been some academic focus on this area. Al-Jarf (2007) conducted a review on the reading curriculum in Saudi Arabia to see how teachers are expected to approach the task of teaching reading in English. Al-Jarf (2007) argued that a number of the reading topics were not interesting to the readers. In addition to this, some other relevant studies in this area have been conducted by Fageeh (2003) Almansour and Alshorman's (2014) and Al-AlOrani (2014) on the connection between reading and writing. This research is potentially significant to the context for three reasons: 1) For learners, a focus on the integration between reading and writing offers the advantage of learning more than one skill at the same time as supported by the Communicative Language Teaching (CLT) theory. Also, integration between reading and writing helps to immerse students in the target language through which, they gain knowledge of the target language culture and norms. It also offers them a fundamental basis to acquire language by using it in their own written texts. 2) For teachers, the focus on combining the two skills will help them improve their instruction by providing learners opportunities to develop both skills at the same time. Moreover, by integrating reading and writing, teachers are able to move away from pedagogies which are heavily based on discrete items of knowledge and assessment, such as grammar translation, and move towards a more constructivist style of instruction whereby students construct their own knowledge based on class materials. 3) The policy makers from ministry of education in Kingdom of Saudi Arabia will get useful feedback to introduce necessary modifications in designing syllabus by integrating reading into writing instruction for the purpose of improving writing skills of EFL leaners and arrange training workshops for English professionals so that they could focus on the significance of reading-writing connection in their pedagogy and instruction.

\section{Literature Review}

\subsection{Current Practices and Research}

It has long been commented that the teaching of writing is "reductionist and mechanistic" and that teachers have failed both in teaching writing effectively and also failed to understand the contextual factors which influence writing (Zamel, 1987, p. 697). If reading is needed to support writing then how can teachers get students to read? There has been renewed interest in the top ten principles of reading as first listed by Williams (1986, cited in Day \& Bamford, 2002) then revised by Day and Bamford and then later revised by Prowse. The first principle states "in the absence of interesting text, very little is possible (Williams, 1986, cited in Day \& Bamford, 2002, p. 137). Pigada and Schmitt, (2006) as well as Briggs (2008), have called for increase interest in literature, and vocabulary in the literature for the teaching of writing skills. Briggs (2008) also calls for renewed attention into the quality of the core texts chosen for study. The need to read in foreign languages seems to be ever increasing (Alderson \& Urquhart, 1984). In education and vocation, there is, and always will be, a need to use the two skills together (Alderson \& Urquhart, 1984). Engineers in South Korea need to read manuals written in English and nurses in the United Arab Emirates need to write patient care records in English. There have not been many studies on the specific differences between L1 reading and L2 reading (Neuman, 1989). However, Alderson and Urquhart (1984) echo what a number of EFL teachers find in that their students fail to effectively learn how to read in the L2. Without a strong L2 reading, L2 writing is clearly troubled. This concept is supported by Huff and Kline (1987) who wrote on audience and context recognition as being a vital pre-requisite of writing. On the positive side, however, it is known that for L1 and L2 writing, the writing skills in L1 are transferable to L2 writing tasks (Silberstein, 1993). Llurda (2006) found in conducting studies with L2 writers that it was 
non-native speaker teachers of writing who had the advantage of knowing which aspects of the L1 writing could be brought into the L2. There are two sources of L2 acquisition. Firstly, there is the knowledge and skills the learners bring from the L1 and then the inputs from the L2. Crucial for the learners, are the forms, processes, and functions of the L2 (Krashen, 1984). It was Krashen's (1984) comprehensible input theory which emphasized the importance of learners being immersed in comprehensible input from the L2. The idea for the more input, the more learning was strongly supported through the 1980s in language teaching (Dubin \& Olshtain, 1980). Quantitative studies by Lee and Lemonnier (1997) and Pigada and Schmitt (2006) maintain that strong readers in L1 will be strong readers in L2, and the same, to a lesser extent, is true of L1 and L2 writing. However, Lee and Lemonnier (1997) found that L1 skills were more transferable to the L2 at elementary level of use and less transferable in advanced level use. They concluded that their findings support the move away from the grammar translation methods of teaching. Thus, there is a need to conduct more studies for investigating the relationships between reading and writing so that we could understand how different reading tasks, such as persuasive reading tasks can match with persuasive writing tasks and how descriptive reading can be linked with descriptive writing (Carroll \& Conner, 2001).

\subsection{The Role of the Teacher}

The role of EFL teachers in facilitating the use of this approach in teaching writing through reading is very important. According to the literature, there is a pursuit to find the best way of teaching writing through reading (Lee \& Lemonnier, 1997; Pigada \& Schmitt, 2006). For a long time, writing teachers have been encouraged to use imaginative role play and ways of finding students' schemata as a means of encouraging great writing in L1 and L2 alike (Miller \& Judy, 1972). Some suggestions for the right way of teaching for the teachers to refer to during the practice are illustrated in three points. First, designing an appropriate program is essential. Such a program needs to be mindful of the students' levels (Carson et al., 1990). Usually, a teacher who is daring enough to experiment in his new teaching area has to rely on his own to develop a course plan or syllabus. This course should be an integrated high level practice for communication through the printed text, as recommended by Krashen's (1984) comprehensible input theory and the teacher should have a clear objective and let the students know it (Carroll \& Conner, 2001). Second, the teacher should also take into consideration the following factors, the course intensity, the participants' age, qualification, reading ability and writing competence (Carson et al., 1990). Third, choosing authentic and meaningful materials is important. As mentioned, some academics recommend reading prescriptions as a means of developing students' writing (Dubin \& Olshtain, 1980). Concrete models of writing should be given to the students so that they can use these models to see where they need to go with their writing. Authenticity, readability and exploitability are espoused by Luo (2005) as important considerations for teachers choosing materials.

\subsection{Advantages and Disadvantages of the Theory of Integration}

Although the practice of teaching English writing by means of integrating it with reading is possible in theory, and it enjoys several obvious advantages over the traditional way of separating writing from reading, there are difficulties in implementing this new approach. It takes both courage and energy of the teacher to try the new approach and to prove that it does work (Luo, 2005). One of the weaknesses of the strategy of using reading as a means to teach writing is that there are so many other methods for teaching writing which seem to operate successfully and do not focus on reading. Examples of this include teaching writing through grammar where teachers focus on grammar correction in the students' writing (Hedgcock \& Lefkowitz, 1996; Luo, 2005). Some researchers advocate using computers as a tool to improve writing. Other methods of teaching writing have been through getting students to compare texts, use writing strategies, and receiving coaching from the teacher (Hedgcock \& Lefkowitz, 1996; Reichelt, 2001). However, it must be said that what holds most of these strategies together is the fact that reading is a pre-requisite in all cases (Reichelt, 2001). Another weakness of the theory is that it could be argued that using reading to improve writing is an inefficient method. In primary school settings, imagination is often used as an incentive for writing and there are text books focusing on using imagination as a means of encouraging writing (Miller \& Judy, 1972). The strength of reading underpinning writing theory is that it maintains that background knowledge is crucial (Carrell \& Eisterhold, 1983). The idea has been established in more mainstream education texts, the idea of constructivism. Put simply, prior knowledge interacts with the incoming input to form new knowledge (Carrell \& Eisterhold, 1983).

\subsection{Theoretical Framework and Research Questions}

This project aims to explore how EFL teachers are currently teaching writing in their various institutions, how they perceive the relationship between reading and writing and what their views are regarding the integration of reading and writing as a means of teaching writing. This project contributes to previous studies in the area, as it 
aims to gather information about teachers because the majority of previous studies in this area focused learners to investigate how different approaches of teaching writing have influenced their educational/learning outcomes. This project aims to expand the work of other scholars who support the integration of reading and writing as a means of teaching writing as it will trial a number of model lesson plans which will provide valuable feedback about their suitability and the greater concept of integrating reading and writing by seeking answers to the following questions:

- How far do Saudi EFL teachers understand and support the theory of integration between reading and writing?

- To what extent do Saudi EFL teachers apply the theory of integration between reading and writing in their practice of teaching English?

\section{Methodology}

In order to determine the extent Saudi EFL teachers support, apply and understand the theory of integration between reading and writing, the researchers compiled two lesson plans, one based on the integration theory and the other is a traditional lesson plan to see which lesson plan teacher-participants chose to teach writing. The researcher then collected the data through structured and semi structured interviews to determine the implications of the results in relation with the objectives of the project. An important part of the data collection in this project was to study not only the qualitative responses from teachers regarding what they know of the integration of reading and writing, how they teach writing, and how they respond to two theoretical questions on teaching philosophy, but to discover if given a choice of two approaches, for example, a traditional lesson plan and a lesson plan based on an integrated approach of reading and writing, which of the two would the teachers choose. To limit some of the extraneous variables in the selection of the lesson plans, there were a number of similarities in the design of the two plans. Firstly, both concerned relative clauses, defining and non-defining. In this way, the teachers were not influenced by the focus of the language rather than the overall lesson approach. Also, the amount of paper work for the two lesson plans was designed to be similar so that neither of the lesson plans looked longer or more troublesome.

\subsection{The Instrument}

A questionnaire containing both open and closed ended questions was designed to gather data on ten teachers' perceptions and understandings of the integration between reading and writing as the means for teaching writing. This instrument focused on teachers' perceptions and behaviors towards teaching writing and specifically, how they perceived an integrated approach to teaching writing. Teachers were encouraged to describe their own approach to teaching writing. The close ended questions focused on more exact responses whether the respondent agreed with 'the theory that says that the most effective way to teach writing is through reading'. Close questions were conducted from each of ten teacher participants to compare what they say and what they do, to rate these lesson plans in terms of their preferences and to get their views on what lesson plans would be most appropriate for the EFL learners.

\subsection{The Participants and Procedure}

Ten experienced Saudi national EFL teachers from a range of teaching institutions in Saudi Arabia were selected for this study. The criteria for the participants were that they needed to have taught EFL for at least three years. As mentioned earlier, the two different lesson plans were distributed among the ten EFL professionals to choose either of them in their practice of teaching writing to their respective students. After two weeks, the questionnaire was distributed to them.

\subsection{Method of Analysis}

For this project, a content analysis was used to gather a proper analysis of the findings. Content analysis is used in situations where it is difficult to directly measure or observe the phenomenon of interest (Fraenkel and Wallen (2003). In this project, the content analysis of the ten teachers' responses was juxtaposed with a comprehensive review of the body of the literature on the topic of reading-writing integration in the EFL classroom. Furthermore, key terms and concepts were defined by the researchers prior to conducting the study to limit ambiguity. In this case, the principal research question was to what extent do Saudi EFL teachers support, practice, and understand the reading-writing integration. Some of the key terms used in the interviews conducted from respondents were 'integration', 'apply', 'agree' or 'disagree'. Once the data was collected, the researcher used a table to quantify the responses of the participants 


\section{Analysis of Findings}

The table below (Table 1) plots the respondents' answers regarding the integration of reading and writing as a means of teaching writing to EFL learners. The first column, 'Understand' refers to whether the respondents were able to indicate in their responses whether they understood what an integrated reading and writing lesson would be like. The second column 'Apply' refers to whether the teachers routinely apply an approach to teaching writing which is in line with an integrated approach as opposed to more traditional writing teaching. The 'Agree with' column indicates whether the teachers agreed that integrating the two skills of reading and writing would be the most effective means of teaching writing. The 'Lesson Plan Selection' column shows whether the participants chose the lesson plan based on the integrated model or the plan based on the traditional model.

Table 1. Quantifying the participants' responses

\begin{tabular}{lllll}
\hline & Understand & Apply & Agree with & Lesson Plan Selection \\
\hline Respondent -1 & + & - & + & + \\
Respondent -2 & - & - & + & + \\
Respondent -3 & - & - & + & + \\
Respondent -4 & - & - & + & - \\
Respondent -5 & + & + & + & + \\
Respondent -6 & - & - & + & + \\
Respondent -7 & - & - & + & - \\
Respondent -8 & - & - & + & + \\
Respondent -9 & - & - & - & - \\
Respondent -10 & - & - & + & - \\
TOTAL & $\mathbf{2 0 \%}$ & $\mathbf{1 0 \%}$ & $\mathbf{9 0 \%}$ & $\mathbf{6 0 \%}$ \\
\hline
\end{tabular}

Overall, the most prevailing trend from the ten respondents was that there is an important link between reading and writing. Ninety percent of the sample, all but one respondent, agreed with the statement 'the most effective way to teach writing is through reading'. Most perceived reading as a necessary source of information or details for writing. Only one respondent, the ninth respondent, disagreed with the statement justifying his/her point of view by saying that reading alone did not improve one's writing skill. Even though $90 \%$ agreed that there was an important link between reading and writing particularly when teaching students how to write, from the responses made by the sample, it seemed that only $20 \%$ had an understanding of the concept of integrating writing and reading. The remaining $80 \%$ seemed to view the link as simply reading as data for writing rather than two intertwined skills. Therefore, after analyzing the results, it was not surprising that only $10 \%$ of the sample, one out of ten, routinely applies a writing teaching approach which resembles an integrated approach in some way. Therefore, most of the sample agrees that there is an important link yet teachers do not seem to understand the exact nature of the link nor do they apply it in the day-to-day teaching. However, something that was interesting was that when given a choice between a lesson plan based on an integrated reading and writing lesson, Lesson Plan 1, and a lesson plan based on a traditional writing lesson, Lesson Plan 2, $60 \%$ of the sample chose the integrated lesson plan, Lesson Plan 1 . Therefore, it seems that while only $10 \%$ apply a similar approach in their current practice, when given the option, $60 \%$ went with the integrated approach at least suggesting that they have a preference for the integration method. In other words, even though their understanding of the principles of the integration of reading and writing were not clear, many teachers chose L1, which indicates that there is something more intrinsically motivating about the face value of the lesson plan.

It is important to look at some of the common themes which ran through the respondents' answers to better understand the situation. Analyzing respondent's answers, there seems to be some contradiction in the responses. Like many of the other respondent's views, respondent 1 said that he/she agreed with the idea, but then other responses made in the survey were dissimilar in opinion. Respondent 2 made a comment which was similar to others in that reading and writing are obviously linked, but that there was nothing special, or nothing especially useful that could be gained from a focus on that combination. Basically, it seemed that most of the teachers still thought of reading and writing as two separate skills that should remain parted. Another common theme among 
teachers indicated that they taught writing through smaller to larger patterns. Respondents 2 and 6 among others said that writing needed to be approached from small units to larger ones. One teacher, respondent 3 , even commented that students needed to be taught how to hold pens. In this light, the teacher seems to be asking for a focus on an aspect of writing even before writing a letter itself. Respondent 4 touched on a similar theme saying that learners needed to know keywords.

There was another group of teachers who stressed the importance of reading for information. The main respondents who supported this view were respondents 4 and 5. Respondent 4 stressed that reading was important to aid readers in terms of providing building blocks for writing. Respondent 4 indicated that he/she focused on teaching keywords to get students used to writing. Also, respondent 4 wrote that reading enabled students to gather names, times, and places which are required for their writing. Respondent 5, on the other hand, suggested that students should read as widely as possible in order to gather the best argument for their writing. This respondent seems to be recommending a study before writing approach, which is similar to what many university students are expected to do. In summary, it could be inferred that respondent 4 supported reading for minimal data whereas respondent 5 supported reading for maximal data. Another occurrence noted from the results was that there was a level of confusion or at least a lack of clarity in the respondents' answers. The third teacher seemed to concentrate more on the mechanical skill of writing than focusing on the issues of motivation or informing writing. It seems that this respondent was either confused by what the questions were seeking or felt strongly that, because reading did not help students in terms of holding a pen, it was not of primary importance. Respondent eight's answers also suggested possible confusion or contradiction. Even though the majority of the respondents agreed that teaching writing through reading was a most effective way of teaching writing, and most of them did not routinely apply it. Respondent 8 was found to comment that he/she agreed with the statement, but then later on, he/she made a different comment by saying that each skill has its own way of teaching.

\section{Discussion of Results}

One of the core objectives of the research project was to determine to what extent do Saudi EFL teachers support, apply and understand the theory of integration between reading and writing. Thus, if this sample is anything to go by, it seems that language teachers recognize a strong and important link between reading and writing. As one of the teachers commented, reading and writing are linked in the same way as listening and speaking. Also, not only did the majority of the sample firmly indicate that there was a link, they also, on the whole, indicated that the lesson plans based on the integration of reading and writing were preferable. In this way, it could be inferred that majority of EFL teachers agree with Alderson and Urquhart (1984) that there is a practical relationship between reading and writing and they support the results of such studies which suggest that teaching writing skills through reading is more effective mode of instruction than merely focusing on exclusive teaching writing skills in EFL classes (Alqadi \& Alqadi, 2013; Almansour \& Alshorman, 2014; Hafiz \& Tudor, 1989; Iwahori, 2008; Janopoulos, 2009; Saleem, 2010; Tsang, 1996). However, the agreement of the participants is limited only to the theoretical level; they need to exert a lot to implement this practical relation in their normal teaching practice. Because, though the teachers agreed with the idea and tend to choose the lesson plan layout including reading and writing, their answers indicated that generally they did not understand the exact nature of the overlap and integration of the two skills. Many were only able to articulate that reading informed writing and did not indicate in their survey responses that they knew of any other advantages of the integration such as motivating writing, making writing more of an authentic task as it is based within a strong context supported by reading activities. Herein lies one of the major points of discussion from the results in that what the teacher says and what he/she does are on the whole remarkably different. As commented above, $90 \%$ of the sample agreed with an approach of combining reading and writing in lessons, and yet only one teacher gave a response concerning their approach to teaching writing which resembled the integrated method. Moreover, only two of the respondents supplied answers to the survey which indicated that they understood what an integrated lesson would mean. It would seem that there is a support for a more integrated approach to teaching writing but those who are on the frontline of teaching writing, the teachers themselves, are either unequipped or unknowledgeable about how to apply an integrated approach to teaching writing. Obviously, they support the concept, but they do not apply it, and this appears to mean teachers do not really understand the concept in practice.

As part of this, many of the teachers while agreeing with the concept of integration between reading and writing, still seem to be teaching writing in steps from small to larger chunks of writing. A number of respondents indicated that in their daily teaching of writing, they focused on teaching key words to sentences, and then from sentences to paragraphs. Others in similar vein, focused on teaching models. Again, these teachers responded that they started with smaller models and moved to larger models. The role of EFL teachers in facilitating the use 
of this approach in teaching writing through reading is very important (Lee \& Lemonnier, 1997; Pigada \& Schmitt, 2006), but Saudi EFL teachers still apply such a model which is termed as 'reductionist and mechanistic' in which teachers fail in both teaching writing effectively and to understand the contextual factors which influence writing (Zamel, 1987). Nonetheless, there are a number of problems with this traditional approach. Firstly, when a student studies with a model of any size, he/she is limited to that model. Whether the teacher is focusing on language at sentence level or the paragraph level, the student does not really see the writing in its context. Essentially, any writing model without supporting background information, which is possible from reading, is completely de-contextualized. The students do not have any opportunity to guess the meaning of words or language constructions from the context because the context is highly limited.

Another problem with the approach of teaching writing with models is that it is a very dull teaching and learning experience. If students are being asked to rote learn writing models, they have very limited intrinsic motivation to do so. It is accepted that students copying out writing models, line for line, are only doing so because of motivation to gain high marks or to pass a test. Teaching writing through models does nothing to motivate students to want to write. Additionally, such a practice of teaching writing skills lacks context. In view of Kroll (1994), such practice, which does not include a context (reading-writing connection) is meaningless. The text needs to be read, and understood, before a meaningful response can be written (Carrell and Eisterhold, 1983; Kroll, 1994). On the whole, the results of the current study support the observations of Alomrani (2014) and findings of Fageeh (2003) that Saudi EFL teachers focus less on reading-writing connection in their instruction of teaching writing skills which is considered one of the main reasons for weak writing skills among EFL Saudi learners. What this suggests is that governing bodies and professional teaching bodies need to look for ways of supporting teachers in applying this approach to teaching writing. The following points contain some suggestions on how the integration of reading and writing can be supported and promoted in the Saudi language classroom.

\subsection{Implications of the Research}

One of the most important implications of this study is that it has highlighted the support from teachers themselves towards a system of integration reading and writing to teach writing. This was an important part of the study as it underpins further study and further development of the integrated approach to teaching writing. Even though the sample size was not large, the qualitative data can be used and the findings are easy to interpret. The findings suggest that teachers agree with the approach and select it given a choice, however, they do not seem to currently understand the approach enough to apply it. Another implication of the study is that it has shed some light on the current teaching practices of EFL teachers regarding the teaching of writing in Saudi Arabia. Documented accounts of specific language teaching approaches in the young nation, particularly accounts in English, has often been difficult to acquire, however, this project has acquired information from a useful sample of language teachers. The findings of the survey were that EFL teachers teaching writing in Saudi, appear to be routinely applying approaches to teaching writing which are based on writing models either in their entirety or broken down into their constitutes and taught step-by-step. Some teachers even seem to focus on more basic manual skills related to writing such as holding the pen correctly.

\subsection{Conclusion}

The major findings of this research project were that for the ten EFL teachers surveyed, almost none of the teachers said that they apply an approach to teaching writing which resembles an integrated approach. Most of the teachers indicated that they usually taught writing as a separate skill apart from reading, and the written content of communication that was analyzed indicated that the teachers taught writing in the traditional way either closely following writing models which the students' rote learn or through focusing on discrete items of writing and building up to larger written constructions. The results from the ten participants' answers also suggested that almost none of the participants were familiar with the concept of the integrating reading and writing for the purposes of teaching writing. The teachers seemed to indicate that the two were linked in a surface way, however, a deeper link between reading and context and motivation were overlooked by the ten teachers. However, most of the respondents did comment that they agree with the idea and given a choice of lesson plan, most of the teachers choose the integrated lesson plan. Thus, it is concluded that although the sample did not apply the concept, they did support it

\subsection{Limitation of the Research}

The first limitation of the study was the sample size. Ten teachers are hardly a representative of the total number of English language teachers in the country. A second study limitation was that there was no qualitative data collected from interviews. The survey research that was conducted involved an emailed questionnaire. There were no face to face interviews with the teachers. Therefore, this indirect sampling method coupled with the 
limited sample of the study meant that the findings of the research need to be treated with some caution. However, both of these two aspects of the research methodology were due to the limited time frame and limited scope of the research project. It was obvious that the researchers needed more time to gather information about the current EFL classroom situation in order to provide a clearer image of the practitioners' perspectives on integrationist approaches to teaching writing in Saudi Arabia. Another limitation of the study was that while the method of study was content analysis, the written content that was gathered was the responses in the participants' second languages, albeit the respondents being English teachers. What this meant is that a number of the responses contained grammatical and lexical errors which created uncertainty about the respondents' perceptions. While the researchers could attain the gist of the respondents' answers in some cases with an amount of guess work, undoubtedly this impinged on the clarity of the responses. Also, this factor may have also been an underlying reason why many of the responses were brief. Even though the questionnaire asked participants to elaborate in their answers, many of the respondents' answers to questions were as short as two sentences. The final limitation of this particular study is the lack of published material. In this study, the researchers had great difficulty in finding academic publications about the teaching of writing and reading in Saudi Arabia. Moreover, there were very few academic accounts of teaching English in general in Saudi Arabia.

\subsection{Recommendations and Further Research}

From the research findings, a number of recommendations can be made, all of which center around supporting EFL teachers adopting an integrated approach. The first recommendation is that teachers must be given an opportunity to better understand the integration theory. It is recommended that EFL teachers in Saudi Arabia, as part of their professional development, receive workshops on how the theory works and how it can be applied in the classroom. In addition, there is also a need to address the syllabi in teachers' colleges where some training sessions must focus on the pedagogy of teaching writing skills through reading as a part of teachers pre-service training program and regular in service training workshops be arranged for English professionals on how to teach writing skills by integrating it with reading. The third area where the integration approach needs to be developed and emphasized is in teaching materials. The majority of textbooks written on teaching writing available in Saudi Arabia heavily focus on the conventions of writing and models of writing. There is a need for a more authentic and motivational approach to writing instruction in the kingdom. All in all, as the teachers themselves have indicated, the integration of reading and writing in teaching writing offers a more interesting framework for students so they must be equipped with essential knowledge to successfully employ this model in their teaching of writing skills to their students. Grabe $(2001 ; 2003)$ highlights the importance of conducting further research on the relationship between reading and writing in general. Specifically, in the EFL context of Saudi Arabia, there are fewer studies conducted by Fageeh (2003) Almansour and Alshorman's (2014) and AlOmrani (2014) on the connection between reading and writing. The current study fills in the gap and hopefully, paves the way to conduct further research in this area for the betterment of EFL profession in Saudi Arabia. The researcher suggests both exploratory and experimental studies on the connection between reading and writing skills to be conducted. The exploratory research may focus on investigating the current practices (pedagogies) of teaching writing skills in EFL classrooms. The experimental studies may focus on the comparative study on the effectiveness of traditional and integrated approaches employed by teachers in teaching the writing skills.

\section{References}

AlOmrani, A. H. (2014). Integrating Reading into Writing Instruction in the EFL Programs at Saudi Universities. Arab World English Journal, 5(3), 100-112.

Alderson, J., \& Urquhart, A. (1984). Reading in a foreign language. London: Longman.

Al-Jarf, R. (2007). Developing Reading and Literacy in Saudi Arabia. Riyadh: King Saud University.

Alqadi, K., \& Alqadi, H. (2013). The effect of extensive reading on developing the grammatical accuracy of the EFL freshmen at Al-Bayt University. Journal of Education and Practice, 6, 106-113.

Almansour, N., \& Alshorman, R. (2014). The effect of an extensive program on the writing performance of Saudi EFL university students. International Journal of Linguistics, 6, 247-264. https://doi.org/10.5296/ijl.v6i2.5551

Briggs, J. (2008). Writing without Reading: The Decline of Literature in the Composition Classroom. Association of Literary Scholars and Critics.

Calkins, L. (1986). The art of teaching writing. Portsmouth: Heinemann.

Carrell, P., \& Connor, U. (1991). Reading and Writing Descriptive and Persuasive Texts. The Modern Language Journal, 75(3), 314-324. https://doi.org/10.1111/j.1540-4781.1991.tb05361.x 
Carrell, P., \& Eisterhold, J. (1983). Schema Theory and ESL Reading Pedagogy. TESOL Quarterly, 17(4), 553-573. https://doi.org/10.2307/3586613

Carson, E., Carrell, P., Silberstein, S., Kroll, B., \& Kuehn, P. (1990). Reading-Writing Relationships in First and Second Language. TESOL Quarterly, 24(2), 245-266. https://doi.org/10.2307/3586901

Carson, J. G., \& Leki, I. (1993). Introduction. In J. G. Carson, \& I. Leki (Eds.), Reading in the composition classroom: Second language perspectives (pp. 1-7). Boston, MA: Heinle \& Heinle Publishers

Day, R., \& Bamford, J. (2002). Top Ten Principles for Teaching Extensive Reading. Reading in a Foreign Language, 14(2).

Dubin, F., \& Olshtain, E. (1980). The Interface of Writing and Reading. TESOL Quarterly, 14(3), 353-363. https://doi.org/10.2307/3586600

Fageeh, A. (2003). Saudi college students' beliefs regarding their English writing difficulties. Unpublished doctoral dissertation, Indiana University of Pennsylvania.

Fraenkel, J., \& Wallen, N. (2003). How to design and evaluate research in education (5th ed). Boston: McGraw Hill.

Grabe, W. (2001). Reading-writing relations: Theoretical perspectives and instructional practices. In D. Belcher, \& A. Hirvela (Eds.), Linking literacies: Perspectives on L2 reading/writing connections (pp. 15-47). Ann Arbor, MI: University of Michigan Press.

Grabe, W. (2003). Reading and writing relations: Second language perspectives on research and practice. In B. Kroll (Ed.), Exploring the dynamics of second language writing (pp. 24-2262). Cambridge: Cambridge University Press. https://doi.org/10.1017/CBO9781139524810.016

Hafiz, F. M., \& Tudor, I. (1989). Extensive reading and the development of language skills. English Language Teaching Journal, 43, 4-13. https://doi.org/10.1093/elt/43.1.4

Hao, X., \& Sivell, J. (2002). Integrating reading and writing in EFL composition in China. Paper presented at the annual $\mathrm{m}$ eeting of the Canadian association of applied linguistics, Humanities and Social Sciences, Congress, Toronto

Huff, R., \& Kline, C. (1987). The contemporary writing curriculum: Rehearsing, composing, and valuing. New York: Teachers College Press.

Hedgcock, J., \& Lefkowitz, N. (1996). Some Input on Input: Two Analyses of Student Response to Expert Feedback in L2 Writing. The Modern Language Journal, 80(3), 287-308. https://doi.org/10.1111/j.1540-4781.1996.tb01612.x

Iwahori, Y. (2008). Developing reading fluency: A study of extensive reading in EFL. Reading in a Foreign Langauge, 20(1), 70-91

Janopoulos, M. (2009). Pleasure reading and writing in a second language: (How) can we make the connection? In A. Cirocki (Ed.), Extensive reading in English language teaching (pp. 429-438). Munich, Germany: Lincom

Krashen, S. (1984). Writing: Research, theory and applications. Torrance: Laredo.

Krashen, S. (1985). The input hypothesis: Issues and implications. Torrance: Laredo.

Kroll, B. (1994). Second language writing: Research insights for the classroom. New York: Cambridge Applied Linguistics. https://doi.org/10.1016/1060-3743(94)90018-3

Lee, J., \& Lemonnier, D. (1997). The Relative Contribution of L2 Language Proficiency and L1 Reading Ability to L2 Reading Performance: A Test of the Threshold Hypothesis in an EFL TESOL Quarterly, 31(4), 713-739. https://doi.org/10.2307/3587757

Llurda, E. (2006). Non-native Language Teachers: Perceptions, challenges and contributions to the profession. Spain: Springer.

Luo, H. (2005). On Teaching College English Writing through Reading. Sino-US English Teaching, 2(9), 67.

Miller, J., \& Judy, S. (1972). Writing in reality. MI, USA: Harper and Row.

Montieth, M., \& Miles, R. (1992). Teaching creative writing: Theory and practice. Oxford Open University Press.

Prowse, P. (2002). Top Ten Principles for Teaching Extensive Reading: A Response. Reading in a foreign 
language, 14(2).

Pigada, M., \& Schmitt, N. (2006). Vocabulary acquisition from extensive reading: A case study. Reading in a Foreign Language, 18(1).

Reichelt, M. (2001). A Critical Review of Foreign Language Writing Research on Pedagogical Approaches. The Modern Language Journal, 85(4), 578-598. https://doi.org/10.1111/0026-7902.00127

Saleem, B. A. A. (2010). Impact of Extensive Reading on Literacy Perceptions and on EFL Writing Quality of English Major Students at the Islamic University of Gaza. MA Thesis. The Islamic University.

Silberstein, S. (1993). State of the Art TESOL Essays. Illinios: TESOL.

Tsang, W. (1996). Comparing the effects of reading and writing on writing proficiency. Applied Linguistics, 17, 210-233. https://doi.org/10.1093/applin/17.2.208

Zamel, V. (1987). Recent Research on Writing Pedagogy. TESOL Quarterly, 21(4), 697-715.

\section{Copyrights}

Copyright for this article is retained by the author(s), with first publication rights granted to the journal.

This is an open-access article distributed under the terms and conditions of the Creative Commons Attribution license (http://creativecommons.org/licenses/by/4.0/). 